\title{
Mental Health Problems Affecting People Who Have HIV and AIDS in Malawi: A Review
}

\author{
Genesis Chorwe-Sungani*, Anthony Sefasi, Mercy Pindani \\ Community and Mental Health Nursing Department, University of Malawi, Blantyre, Malawi \\ Email: *genesischorwe@kcn.unima.mw
}

Received 25 February 2015; accepted 12 March 2015; published 16 March 2015

Copyright (C) 2015 by authors and Scientific Research Publishing Inc.

This work is licensed under the Creative Commons Attribution International License (CC BY). http://creativecommons.org/licenses/by/4.0/

(c) (†) Open Access

\begin{abstract}
Malawi is located in the southern part of Africa with a population of more than $\mathbf{1 6}$ million people. The country is ravaged with HIV and AIDS epidemic of which the prevalence rate is at $14 \%$. The people who have HIV/AIDS are also affected by mental and psychological disorders. Nevertheless, very little is known about mental health care of people who have HIV and AIDS in Malawi. We did literature search using AJOL, Proquest, PsychINFO, Google Scholar and HINARI search engines and the search yielded scanty (12) research studies on the mental health of people with HIV and AIDS that were conducted in Malawi between 2006-2014. Twelve (12) studies that were reviewed focused on prevalence of mental disorders among people who have HIV and AIDS; nurses' knowledge and skills for providing mental health care to people living with HIV and AIDS (PLWHA); perceived risk of HIV infection among people who have mental health problems; substance abuse and HIV/AIDS issues and awareness of interaction between HIV/AIDS and Mental health. In conclusion, the review shows that people with HIV infection are also affected by mental health problems such as depression and substance abuse. They receive some mental health care in general settings at ART clinics because mental health care is integrated into general health care delivery system. Therefore, it is necessary that health professionals who are generalists should be equipped with adequate knowledge and skills for providing mental health care to care to people with HIV and AIDS.
\end{abstract}

\section{Keywords}

Mental Health Care, HIV and AIDS, Mental Disorders

\section{Introduction}

Malawi is located in the southern part of Africa. The country has an estimated population of more than 16 mil${ }^{*}$ Corresponding author.

How to cite this paper: Chorwe-Sungani, G., Sefasi, A. and Pindani, M. (2015) Mental Health Problems Affecting People Who Have HIV and AIDS in Malawi: A Review. Open Journal of Nursing, 5, 189-194.

http://dx.doi.org/10.4236/ojn.2015.53023 
lion people. The majority of these people (80\%) live in rural areas and survive on less than a dollar per day. The country is ravaged with HIV and AIDS epidemic of which the prevalence rate is at $14 \%$ [1]. The people who have HIV/AIDS in Malawi like elsewhere are also affected by mental and psychological disorders [2]-[5]. Mental health and HIV and AIDS are interlinked such that mental disorders are associated with increased risk of HIV infection and AIDS and interfere with their treatment, and on the other hand some mental disorders occur as a direct result of HIV infection [1]. Despite the fact that mental health and HIV and AIDS are linked, very little is documented about mental health problems that affect people who have HIV and AIDS in Malawi. The delivery of mental health care to people who have HIV and AIDS is important because apart from the physical illnesses associated with the virus, these people are also affected by mental disorders [6]-[9]. Hence HIV and AIDS intervention programmes must include mental health care if they are going to be successful [7]. Providing mental health care to PLWHA may be helpful in preventing further spread of the infection and improving the quality of life of those affected [10].

\section{Methods}

We utilsed AJOL, PsychINFO, Proquest, Google Scholar and HINARI search engines to look for articles using combinations of the following search terms: Malawi AND HIV and AIDS mental disorders, mental illness, mental health, anxiety disorders, mood disorders, adjustment disorders, schizophrenia and psychosis, mental health care and psychiatric disorders. The search yielded scanty (12) research studies in English language that were conducted in Malawi. We also searched for the references cited in relevant studies. We reviewed studies that were published from 2006-2014 that focused on the mental health of people with HIV and AIDS in Malawi. These studies included quantitative and qualitative studies. We did not find any study that was published before 2006.

\section{Results}

Twelve (12) studies were reviewed. Four studies reported on prevalence mental disorders among people who have HIV and AIDS. Three studies reported about nurse's provision of mental health care to PLWHA in Blantyre district. Another study looked at perceived risk of HIV infection among people who have mental health problems. Three studies examined the substance abuse and HIV/AIDS issues. One study looked at youth awareness of interaction between HIV/AIDS and Mental health. The detailed results are presented in Table 1.

\section{Discussion}

\subsection{Common Mental Health Problems Affecting People Who Have HIV and AIDS}

We found that there are very few studies that were conducted to investigate prevalence of mental disorders among people who have HIV infection in Malawi. We reviewed only four studies that had investigated the magnitude and nature of mental disorders that affect people who have HIV and AIDS in the country. It is clear that people with HIV and AIDS are also affected with various forms of mental disorders [11]. A study that was conducted among HIV positive people who were attending Antiretroviral Therapy (ART) clinics in Mzuzu found $14.4 \%$ as a prevalence rate of psychological distress among these people [4]. Similar studies have indicated that almost half of people who have HIV and AIDS in Africa suffer from some form of mental disorder, commonly depression [2]. This is true for Malawi where a study that was conducted among mothers of infants in Malawi, found that depression and anxiety are associated with HIV infection [12]. We also discovered that the prevalence of substance use among people with HIV/AIDS in Malawi is high. For instance, one study revealed that 25.5\% of cannabis (chamba) and alcohol abusers were HIV positive in the country [13]. But worthy noting is that there are no studies that have been conducted to elucidate the prevalence of psychotic disorders among HIV positive people in Malawi. However, studies that were conducted elsewhere show that the prevalence of psychotic disorders among people with HIV infection ranges from 3\% to 23\% [14]. This is a call for concern because the utilization of HIV-services among psychiatric patients is low in some parts of Malawi [15] and their condition may lead to HIV treatment nonadherence. Therefore, more studies should be conducted to explore the prevalence of psychosis and other mental disorders among people with HIV infection across the country. The findings of such studies will help in informing the HIV and AIDS interventions targeting people with mental disorders which are being implemented across Malawi. It is evident that the individual's perceived risk of infec- 
Table 1. Summary of studies that were conducted in Malawi on mental health and HIV/AIDS.

\begin{tabular}{|c|c|c|c|}
\hline Author & Study site & Samples & Study design \\
\hline $\begin{array}{l}\text { Bisika } \\
\text { et al., } \\
\text { (2008) }\end{array}$ & $\begin{array}{l}\text { Thyolo } \\
\text { District } \\
\text { Hospital }\end{array}$ & $\begin{array}{l}\mathrm{N}=200 \text { men } \\
\text { and women } \\
\text { who abuse } \\
\text { drugs }\end{array}$ & $\begin{array}{c}\text { Descriptive } \\
\text { survey }\end{array}$ \\
\hline $\begin{array}{l}\text { Chorwe- } \\
\text { Sungani } \\
\text { (2013) }\end{array}$ & $\begin{array}{l}\text { Blantyre } \\
\text { District }\end{array}$ & $\mathrm{N}=109$ nurses & $\begin{array}{c}\text { Descriptive quantitative } \\
\text { survey adapted Mental } \\
\text { Health Problems Perception } \\
\text { Questionnaire (MHPPQ) }\end{array}$ \\
\hline
\end{tabular}

Chorwe-

Sungani \&

Shangase

(2013)

Chorwe-

Sungani,

Shangase

\& Chilinda

(2014)

$\begin{array}{cc} & \text { Rumphi, } \\ \text { Hsieh } & \text { Mchinji } \\ \text { (2013) } & \text { and } \\ & \text { Balaka } \\ & \text { Districts }\end{array}$

Jere et al., Ntcheu

(2013) District

Jere et al.,

(2012)

John-

Langba

et al.,

(2006)

Blantyre

District

Blantyre

District

Malawi
$\mathrm{N}=136$ nurses

$\mathrm{N}=109$ nurses

Descriptive quantitative survey adapted Mental Health Problems Perception Questionnaire (MHPPQ)

Longitudinal study women aged between 15 and 49years (1541) and their spouses (1065)

\section{8 key leaders} 15 young men Systematic observation of the market place and surrounding establishments

Focus group data from 10 rural villages 3 focus groups in young men (10 - 19 years)

Focus group discussion: 6 female youths and 11 adults (5 male, 6 female)

$\mathrm{N}=3800$ adolescents

(12 - 19 year olds)

Qualitative
ethnographic study

Content analysis using constant comparative method guided by ecological perspective
Descriptive quantitative survey adapted Mental Health Problems Perception Questionnaire (MHPPQ)

Overall prevalence rate for HIV was 25.5\% 81.3\% were abusing cannabis (Chamba) $18.3 \%$ were abusing and alcohol $25.5 \%$ of participants who abused cannabis were HIV-positive

$31.1 \%$, of alcohol abusers were HIV positive

Nurses lack knowledge and skills for providing mental health care to people with HIV and AIDS $53.2 \%$, lacked knowledge and skills to care for people living with HIV and AIDS who have mental health problems

Study findings revealed that there is a linear relationship between general nurses' levels of knowledge and skills and their therapeutic commitment( $r=0.40, \mathrm{n}=136, \mathrm{p}=0.05)$ to provide mental health care of people living with HIV/AIDS $45.6 \%$ of the participants reported that they did not want to work with people with mental health problems who have HIV/AIDS

Most of the general nurses do not feel confident about caring for people with HIV/AIDS who have mental health problems and the nurses do not always receive the support they need $64.2 \%$ of participants reported that they do not feel comfortable when caring for people with mental health problems who have HIV/AIDS

Mental health and the perceived risk of HIV infection are negatively correlated $(\mathrm{r}=-0.19, \mathrm{p}<0.05)$. HIV perception has a significant influence on emotional/affective well-being The perceived risk of infection has a strong negative relationship with mental health outcomes

There were three patterns among young men Alcohol and marijuana were two substances commonly used by young men

Substance use was linked to sex with multiple partners and irregular use of condoms

Young men engaged in alcohol use and risky behaviours despite availability of condoms Young men perceived a direct link between alcohol and unsafe sexual practices

Use of alcohol and other substances are associated with risky sexual behaviors and especially with multiple sexual partnerships and limited use of condoms

$68 \%$ of sexually active adolescents that have ever drank alcohol in Malawi did not use condoms during their last sexual intercourse with a most recent partner

$74 \%$ of adolescents that had ever used a mood altering drug in Malawi did not use a condom during their last sexual intercourse 


\section{Continued}

\begin{tabular}{|c|c|c|c|c|}
\hline $\begin{array}{l}\text { Kim et al., } \\
\text { (2013) }\end{array}$ & $\begin{array}{l}\text { Antiretroviral } \\
\text { Clinics in } \\
\text { Central and } \\
\text { Southern } \\
\text { Malawi }\end{array}$ & $\begin{array}{c}\mathrm{N}=562 \text { adolescents } \\
\text { (female and male) }\end{array}$ & $\begin{array}{l}\text { Cross-sectional design } \\
\text { Beck’s Depression } \\
\text { Inventory-II (BDI-II), } \\
\text { Childrens's Depression } \\
\text { Inventory-2 (CDI-2) and } \\
\text { Children's Depression } \\
\text { Rating Scale-Revised } \\
\text { (CDRS-R) }\end{array}$ & $\begin{array}{l}\text { There is high prevalence of depression } \\
\text { among HIV infected adolescents in Malawi. } \\
\text { BDI-II: } 25.6 \% \text { with depression } \\
\text { CDI-2: } 20.8 \% \text { with depression } \\
\text { CDRS-R: } 18.9 \text { with depression }\end{array}$ \\
\hline $\begin{array}{l}\text { Lommerse } \\
\text { et al., } 2013\end{array}$ & Thyolo & $\begin{array}{l}\mathrm{N}=174 \text { patients } \\
\text { with } \\
\text { neuropsychiatric } \\
\text { disorders }\end{array}$ & $\begin{array}{c}\text { Descriptive } \\
\text { cross-sectional } \\
\text { study }\end{array}$ & $\begin{array}{l}\text { Overall HIV prevalence was } 14.8 \% \text {. } \\
\text { HIV-prevalence among participants with } \\
\text { psychiatric conditions was } 17.7 \% \\
\text { HIV-prevalence among participants with } \\
\text { epilepsy was } 12.8 \% \text { The uptake of HIV-services } \\
\text { among HIV-positive patients was low } \\
\text { - } 35 \% \text { of HIV positive patients did not use } \\
\text { recommended prophylactic therapy } \\
\text { 44\% of HIV positive patients were not } \\
\text { receiving antiretroviral treatment (ART) had } \\
\text { never been assessed for ART eligibility } \\
\text { Overall sexual activity rate was } 61 \% \text {, and } 9 \% \\
\text { of sexually active participants had multiple } \\
\text { partners. } 89 \% \text { did not use condoms consistently } \\
\text { with stable sexual partners } 79 \% \text { did not use } \\
\text { condoms consistently with occasional } \\
>50 \% \text { patients did not know HIV status of their } \\
\text { sexual partners }\end{array}$ \\
\hline $\begin{array}{l}\text { Mwale } \\
\text { et al., } \\
\text { (2007) }\end{array}$ & $\begin{array}{l}\text { Mzuzu Central } \\
\text { Hospital and St. } \\
\text { Johns Hospital } \\
\text { in Mzuzu } \\
\text { AntiRetroviral } \\
\text { Clinics }\end{array}$ & $\begin{array}{l}\mathrm{N}=440 \text { men } \\
\text { and women }\end{array}$ & $\begin{array}{l}\text { Cross-sectional } \\
\text { survey }\end{array}$ & $\begin{array}{l}\text { Psychological distress among people living with } \\
\text { HIV and AIDS go undiagnosed in ARV } \\
\text { clinics 14.4\% with psychological distress and } \\
\text { 4.5\% with suicidal feelings }\end{array}$ \\
\hline $\begin{array}{l}\text { Wright } \\
\text { et al., } \\
2007\end{array}$ & $\begin{array}{l}\text { Zomba } \\
\text { District }\end{array}$ & $\begin{array}{l}12 \text { existing groups of } \\
\text { secondary school } \\
\text { students, orphans and } \\
\text { vulnerable children, } \\
\text { teenage mothers, and } \\
\text { out-of-school youths } \\
6 \text { to } 9 \text { participants per } \\
\text { group } \\
\text { aged between } 14 \\
\text { and } 20 \text { years }\end{array}$ & Exploratory study & $\begin{array}{l}\text { Respondents demonstrated awareness of a } \\
\text { link between mental health concerns and HIV } \\
\text { HIV/AIDS was seen as having psychological } \\
\text { impact on mental health of young people } \\
\text { HIV or AIDS was identified as one of the } \\
\text { reasons for a character's trauma }\end{array}$ \\
\hline
\end{tabular}

tion with HIV negatively influences mental health outcomes [16]. Health workers should endeavour to deal with individuals' misperceptions of their HIV status as a way of promoting mental health.

Three studies that we reviewed indicated that some people who abuse psycho active substances are also affected with HIV and AIDS. One study found that for HIV prevalence rate among people who abuse drugs and alcohol was $25.5 \%$ [13]. The commonly abused substances were cannabis (81.3\%) and alcohol (18.3\%). These commonly abused substances are usually cheaper and easily accessed by the abusers in Malawi. Substance abuse is associated with HIV and AIDS such that behaviors related to drug abuse are some of the major factors that increase the spread of HIV infection [13]. It is a of public health concern that one study found that young men in the country who abuse alcohol engaged in risky sexual behaviours [17]. This is corroborated by John-Langba and colleagues [18] who found that many adolescents in Malawi have ever used alcohol (68\%) or drugs (74\%) and did not use condom during their last sexual intercourse. This shows that drug and alcohol use are some of the factors fuelling the spread of HIV infection among the youths. Hence we suggest that HIV interventions targeting the youths and other population groups in the country should also include the aspect of drug and alcohol abuse since there is a direct link between alcohol and unsafe sexual practices. 


\subsection{Provision of Mental Health Care to People with HIV Infection}

In Malawi, mental health services are integrated into the general health care delivery system so that people can access the services at Central Hospitals, District Hospitals, Community Hospitals, Health Centres and Outreach. This means that people living with HIV and AIDS can access mental health care in general settings at Anti Retroviral Clinics. Nurses, Clinical Officers, Medical Assistants and Physicians who have not specialized in mental health attend to mental health problems of these people. This helps in reducing the patients' burden of moving from place to place to get services they need. However, it is documented that most health workers in Malawi feel neither confident nor competent when dealing with the mental disorders of their clients [19] [20]. This is corroborated by Chorwe-Sungani who found that that more than half of the nurses (53.2\%) did not have knowledge and skills to care for people with co-morbidity of HIV and AIDS and mental disorders[21]. This implies that people with co-morbidity of HIV infection and mental disorders do not always access appropriate mental health care in general settings. Consequently, many of these people end up being referred to mental hospitals which are far away from their homes.

In Malawi there is one government mental hospital and another one run by missionaries [21]. There are inadequate mental health specialists to serve about 16 million people [22]. The country is served by one Psychiatrist; 29 psychiatric clinical officers; 233 psychiatric nurses in Malawi; 2 social workers; 3 Occupational therapists; and 5 Psychologists working in public health sector. These health professionals provide specialized mental health care to people living with HIV and ADIS who have mental disorders. But it is clear that mental health professionals are not adequate and this poses a serious challenge in the provision of mental health care to people with HIV infection and the entire population. Therefore, it is right and proper that in this situation where mental health specialists are few, they should be deployed appropriately and non-specialised health professionals are equipped with relevant knowledge and skills through ongoing in-service mental health education and support from mental health specialists. This will help the health professionals to be competent enough to ably provide mental health care to people with HIV infection across the country. It is clear that nurses who perceive themselves as having adequate knowledge and skills for dealing with mental health problems are more likely to be willing to provide mental health care to people living with HIV/AIDS [23].

\section{Conclusion}

The review shows that people with HIV infection are also affected by mental health problems such as depression and substance abuse. They receive some mental health care in general settings at ART clinics because mental health care is integrated into general health care delivery system. Therefore, it is necessary that health professionals who are generalists should be equipped with adequate knowledge and skills for providing mental health care to care to people with HIV and AIDS.

\section{Acknowledgements}

We thank all those who assisted us during literature search.

\section{References}

[1] WHO (2008) HIV/AIDS and Mental Health. http://apps.who.int(2008)./gb/ebwha/pdf_files/EB124/B124_6-en.pdf

[2] Brandt, R. (2009) The Mental Health of People Living with HIV/AIDS in Africa: A Systematic Review. African Journal of AIDS Research, 8, 123-133. http://dx.doi.org/10.2989/AJAR.2009.8.2.1.853

[3] Collins, P.Y., Holmand, A.R., Freemane, M.C. and Patel, V. (2006) What Is the Relevance of Mental Health to HIV/AIDS Care and Treatment Programs in Developing Countries? A Systematic Review. AIDS, 20, 1571-1582. http://dx.doi.org/10.1097/01.aids.0000238402.70379.d4

[4] Mwale, C.M., Stewart, R. and Mathanga, D. (2007) The Prevalence of Psychological Distress and Associated Factors among People Living with AIDS Attending Antiretroviral Therapy Clinics in Mzuzu, Malawi: A Cross Sectional Descriptive Study. Malawi Medical Journal, 19, 56.

[5] Myer, L., Smit, J., Roux, L.L., Parker, S., Stein, D.J. and Seedat, S. (2008) Common Mental Disorders among HIVInfected Individuals in South Africa: Prevalence, Predictors, and Validation of Brief Psychiatric Rating Scales. AIDS Patient Care and STDs, 22, 147-158. http://dx.doi.org/10.1089/apc.2007.0102

[6] Freeman, M., Nkomo, N., Kafaar, Z. and Kelly, K. (2007) Factors Associated with Prevalence of Mental Disorder in 
People Living with HIV/AIDS in South Africa. AIDS Care, 19, 1201-1209. http://dx.doi.org/10.1080/09540120701426482

[7] Freeman, M., Patel, V., Collins, P. and Bertolote, J.M. (2005) Integrating Mental Health in Global Initiatives for HIV/ AIDS. British Journal of Psychiatry, 187, 1-3. http://dx.doi.org/10.1192/bjp.187.1.1

[8] Mellins, C.A., Kang, E., Leu, C., Havens, J. and Chesney, M.A. (2003) Longitudinal Study of Mental Health and Psychosocial Predictors of Medical Treatment Adherence in Mothers Living with HIV Disease. AIDS Patient Care and STDs, 17, 407-416. http://dx.doi.org/10.1089/108729103322277420

[9] Wright, J., Lubben, F. and Mkandawire, M. (2007) Young Malawians on the Interaction between Mental Health and HIV/AIDS. African Journal of AIDS Research, 6, 297-304. http://dx.doi.org/10.2989/16085900709490425

[10] Lazarus, R. and Freeman, M. (2009) Primary-Level Mental Health Care for Common Mental Disorder in ResourcePoor Settings: Models \& Practice. A Literature Review. Medical Research Council, Pretoria.

[11] Kim, M.H., Mazenga, A.C., Devend, R.A., Ahmed, S., Sharp, C., Mhango, J.K., et al. (2013) Prevalence of Depression amongst HIV Infected Adolescents in Malawi. Proceedings of the 7th IAS Conference on HIV Pathogenesis, Treatment and Prevention, Kualar Lumpur, 30 June-03 July 2013. http://pag.ias2013.org/Abstracts.aspx?AID=1310

[12] Stewart, R.C., Bunn, J., Vokhiwa, M., Umar, E., Kauye, F., Fitzgerald, M., et al. (2010) Common Mental Disorder and Associated Factors amongst Women with Young Infants in Rural Malawi. Social Psychiatric Epidemiology, 45, 551559.

[13] Bisika, T., Konyani, S., Chamangwana, I. and Khanyizira, G. (2008) An Epidemiologic Study of Drug Abuse and HIV and Aids in Malawi. African Journal of Drug \& Alcohol Studies, 2, 781-787.

[14] Nebhinani, N. and Mattoo, S.K. (2013) Psychotic Disorders with HIV Infection: A Review, German Journal of Psychiatry, 16, 43-48.

[15] Lommerse, K., Stewart, R.C., Chilimba, Q., van den Akker, T. and Lund, C. (2013) A Descriptive Analysis of HIV Prevalence, HIV Service Uptake, and HIV-Related Risk Behaviour among Patients Attending a Mental Health Clinic in Rural Malawi. PLOS ONE, 8, e72171.

[16] Hsieh, N. (2013) Perceived Risk of HIV/AIDS Infection and Mental Well-Being in Rural Malawi. Demographic Research, 28, 373-408. http://dx.doi.org/10.4054/DemRes.2013.28.13

[17] Jere, D. (2013) Contextual Factors and Sexual Risky Behaviours for Young Men Working at Roadside Market in Rural Malawi. Ph.D. Thesis, University of Illinois at Chicago, Chicago.

[18] John-Langba, J., Ezeh, A., Guiella, G., Kumi-Kyereme, A. and Neema, S. (2006) Alcohol, Drug Use, and Sexual-Risk Behaviors among Adolescents in Four Sub-Saharan African Countries. http://paa2006.princeton.edu/papers/61153

[19] Kauye, F. (2008) Management of Mental Health Services in Malawi. African Journal of Psychiatry, 5, 29-30.

[20] Chorwe-Sungani, G., Shangase, N. and Chilinda, I. (2014) Care of Patients in Malawi Who Have HIV/AIDS and Mental Health Problems. Mental Health Practice, 17, 35-39. http://dx.doi.org/10.7748/mhp2014.04.17.7.35.e849

[21] Chorwe-Sungani, G. (2013) Nurses' Knowledge and Skills in Providing Mental Health Care to People Living with HIV/AIDS in Malawi. Journal of Psychiatric Mental Health Nursing, 20, 650-654. http://dx.doi.org/10.1111/jpm.12062

[22] WHO (2005) Mental Health Atlas. http://www.who.int/mental health/evidence/mhatlas05/en/index.html

[23] Chorwe-Sungani, G. and Shangase, N. (2013) Therapeutic Commitment for General Nurses in Dealing with Mental Health Problems of People Living with HIV/AIDS in Blantyre, Malawi. Malawi Medical Journal, 25,110-113. 